\title{
Insulin Release from Human Pancreatic Islets In Vitro
}

\author{
A. M. Grant, M. R. Christie, and S. J. H. Ashcroft \\ Nuffield Department of Clinical Biochemistry, John Radcliffe Hospital, Headington, Oxford, England
}

Summary. Islets of Langerhans were isolated by collagenase digestion from the pancreas of a 39 year-old female renal transplant donor. The islets were subjected to three consecutive periods of tissue culture, after each of which they were incubated in vitro with various agents whose effects on insulin release from islets of laboratory animals have previously been established. After the first culture period, the basal insulin secretion rate of $5.2 \mu \mathrm{U} /$ islet/h seen with $2 \mathrm{mmol} / 1 \mathrm{glucose}$ was increased approx. 5 -fold on raising the glucose concentration to $20 \mathrm{mmol} / \mathrm{l}$. The islets retained the insulin-secretory response to $20 \mathrm{mmol} / \mathrm{l}$ glucose throughout the period of study. Insulin secretion was also stimulated by mannose, leucine, $\alpha$-ketoisocaproate, dihydroxyacetone and 3-hydroxybutyrate, but not by fructose or N-acetylglucosamine. Fructose however increased insulin release in the presence of $4 \mathrm{mmol} / \mathrm{l}$ glucose. Caffeine elicited insulin release in the absence of glucose and enhanced insulin release in response to $10 \mathrm{mmol} / 1$ glucose. Glucose-stimulated insulin release was inhibited by trifluoperazine $(25 \mu \mathrm{mol} / \mathrm{l})$.

Key words: Insulin secretion, human islets of Langerhans, pancreatic $\beta$-cell, tissue culture.

Since the introduction of methods for the isolation of viable islets of Langerhans $[1,2]$ much insight has been gained into the process of insulin secretion and its regulation. However, current views are based almost entirely on studies from islets of laboratory animals particularly rat and mouse. To what extent such ideas are applicable to man is uncertain in view of the paucity of information on secretory responses of human islets. In the present study, the removal of pancreas from an adult patient shortly after death provided an opportunity to assess some of the properties of insulin release in vitro: maintenance of islets in tissue culture permitted several experiments to be performed on the same preparation of islets.

\section{Methods}

Part of the tail of the pancreas was obtained within $1 \mathrm{~h}$ of death from a female renal transplant donor aged 39 years who had died as a result of a subarachnoid haemorrhage; the patient had a previously unremarkable medical history. The pancreas specimen was distended with ice-cold Krebs bicarbonate medium $\mathrm{pH}$ 7.4, [3]; $1 \mathrm{~g}$ pieces were then digested with Sigma (Type II) collagenase $(5 \mathrm{mg} /$ $\mathrm{ml}$ ) [4]. Islets were harvested with a wire-loop and transferred to tissue culture medium in $5 \mathrm{ml}$ Petri dishes. The culture medium was RPMI 1640 (Gibco Europe Ltd., P. O. Box 35, Paisley, Scotland) containing glucose $(11 \mathrm{mmol} / \mathrm{l})$, penicillin $(0.1 \mathrm{mg} / \mathrm{ml})$, streptomycin $(0.1 \mathrm{mg} / \mathrm{ml})$ and $10 \%(\mathrm{v} / \mathrm{v})$ inactivated calf-serum (Wellcome Reagents Ltd., Beckenham, Kent, U.K.).

Approximately 500 islets were obtained from $7 \mathrm{~g}$ of pancreas. The islets were cultured overnight at $37^{\circ}$ in an atmosphere of air: $\mathrm{CO}_{2}(95: 5)$ saturated with $\mathrm{H}_{2} \mathrm{O}$ vapour. For measurement of insulin release, islets were washed with ice-cold bicarbonate medium containing glucose $(2 \mathrm{mmol} / \mathrm{l})$ : batches of 5 islets were then incubated at $37^{\circ}$ for $2 \mathrm{~h}$ in $0.6 \mathrm{ml}$ bicarbonate medium containing albumin $(2 \mathrm{mg} / \mathrm{ml})$ and gassed with $\mathrm{O}_{2}: \mathrm{CO}_{2}(95: 5)$. The concentrations of glucose and other additions are as shown in the Tables. After incubation the medium was separated by centrifugation and aspiration, diluted with $40 \mathrm{mmol} / \mathrm{l}$ phosphate buffer, $\mathrm{pH}$ 7.4 containing albumin $(0.1 \%)$ and merthiolate $(6 \mathrm{mmol} / \mathrm{l})$ and stored at $-20^{\circ}$ until assayed for insulin by a charcoal radioimmunoassay [5], using an MRC reference standard of human insulin (batch 66/304): the minimal detectable value was $5 \mu \mathrm{U} / \mathrm{ml}$. The islets were returned to culture for a further $24 \mathrm{~h}$ when a second insulin release experiment was performed as above. A third release study was conducted on the same islets after a further period of $24 \mathrm{~h}$ in tissue culture.

Results are expressed in $\mu \mathrm{U}$ insulin per islet per hour as mean \pm SEM with the number of batches of islets shown in parentheses. The significance of differences was assessed by the two-tailed Student's t-test. 
Table 1. Insulin release from human islets cultured overnight

\begin{tabular}{|c|c|c|c|c|c|}
\hline $\begin{array}{l}\text { Glucose concentration } \\
(\mathrm{mmol} / \mathrm{l})\end{array}$ & \multicolumn{2}{|c|}{ Other addition $(\mathrm{mmol} / \mathrm{l})$} & $\begin{array}{l}\text { Insulin release } \\
\mu \mathrm{U} / \text { islet } / \mathrm{h}\end{array}$ & $\mathrm{n}$ & $\mathrm{p}$ \\
\hline 2 & \multicolumn{2}{|l|}{-} & $5.2 \pm 1.3$ & (5) & - \\
\hline 4 & \multicolumn{2}{|l|}{-} & $9.6 \pm 2.3$ & (5) & NS \\
\hline 20 & \multicolumn{2}{|l|}{-} & $29.3 \pm 2.6$ & (5) & $\leqslant 0.001$ \\
\hline- & $\mathrm{N}$-acetylglucosamine & 20 & $5.9 \pm 2.0$ & (5) & NS \\
\hline- & Leucine & 20 & $12.7 \pm 2.1$ & (5) & $\leqslant 0.05$ \\
\hline- & $\alpha \approx$ ketoisocaproate & 20 & $22.8 \pm 2.8$ & (5) & $\leqslant 0.001$ \\
\hline- & Fructose & 20 & $6.6 \pm 2.0$ & (5) & NS \\
\hline 4 & Fructose & 20 & $18.1 \pm 4.0$ & (5) & $\leqslant 0.05$ \\
\hline- & $\beta$-hydroxybutyrate & 20 & $11.1 \pm 1.7$ & (5) & $\leqslant 0.05$ \\
\hline
\end{tabular}

Batches of 5 islets were cultured overnight and then incubated in bicarbonate medium containing albumin $2 \mathrm{mg} / \mathrm{ml}$ with glucose and other additions as stated for $2 \mathrm{~h}$ at $37^{\circ}$. Insulin released into the medium was assayed by radioimmunoassay. Results are given as mean \pm SEM with the number of observations shown. Following incubation the islets were recultured. The significance of the difference to the insulin release at $2 \mathrm{mmol} / \mathrm{l}$ glucose was assessed by two-tailed Student's t-test

Table 2. Insulin release from human islets cultured for 2-3 days

\begin{tabular}{|c|c|c|c|c|c|c|}
\hline Line & $\begin{array}{l}\text { Glucose concentration } \\
(\mathrm{mmol} / \mathrm{l})\end{array}$ & \multicolumn{2}{|c|}{ Other additions (mmol/l) } & $\begin{array}{l}\text { Insulin release } \\
\mu \mathrm{U} / \text { islet } / \mathrm{h}\end{array}$ & $\mathrm{n}$ & $\mathrm{p}$ \\
\hline 1 & 0 & \multicolumn{2}{|l|}{ - } & $1.9 \pm 0.3$ & (5) & - \\
\hline 2 & 10 & \multirow{2}{*}{\multicolumn{2}{|c|}{$\begin{array}{ll}- \\
-\end{array}$}} & $12.4 \pm 2.1$ & (5) & $<0.01$ \\
\hline 3 & 20 & & & $24.0 \pm 5.1$ & (5) & $<0.05$ \\
\hline 4 & - & \multicolumn{2}{|l|}{ Mannose } & $11.8 \pm 4.3$ & (5) & $<0.05$ \\
\hline 5 & - & Dihydroxyacetone & 20 & $5.5 \pm 0.8$ & (5) & $<0.01$ \\
\hline 6 & - & $\mathrm{N}$-acetylglucosamine & 20 & $1.9 \pm 0.3$ & (5) & NS \\
\hline 7 & - & Caffeine & 5 & $8.7 \pm 1.8$ & $(5)$ & $<0.05$ \\
\hline 8 & 10 & Caffeine & 5 & $24.5 \pm 4.4$ & (5) & $<0.01$ \\
\hline 9 & 20 & Trifluoperazine & 0.025 & $7.0 \pm 1.3$ & (5) & $<0.05^{\mathrm{a}}$ \\
\hline 10 & 2 & - & & $3.4 \pm 0.6$ & (5) & - \\
\hline 11 & 20 & - & & $19.5 \pm 5.3$ & (4) & $<0.05$ \\
\hline 12 & - & $\mathrm{N}$-acetylglucosamine & 20 & $2.3 \pm 0.2$ & (5) & NS \\
\hline 13 & 2 & $\mathrm{~N}$-acetylglucosamine & 20 & $2.8 \pm 0.4$ & (5) & NS \\
\hline
\end{tabular}

The islets used for the experiments of Table 1 were recultured for $24 \mathrm{~h}$ and then incubated as before (lines 1-9). After this incubation, a further period of $24 \mathrm{~h}$ in culture was followed by a third incubation for insulin release measurement (lines 10-13). For details see Table 1 .

${ }^{\mathrm{a}} \mathrm{p}$ value compared to $20 \mathrm{mmol} / \mathrm{l}$ glucose

\section{Results}

After overnight culture, human islets responded to an increase in medium glucose concentration from 2 to $20 \mathrm{mmol} / \mathrm{l}$ with a 6 -fold increase in the amount of insulin released (Table 1). Sensitivity to glucose was retained although somewhat diminished on two successive occasions when the islets had been returned to culture for $24 \mathrm{~h}$ and then reincubated (Table 2).

Insulin release was also stimulated by mannose and by dihydroxyacetone but not by fructose or by $\mathrm{N}$-acetylglucosamine (Tables 1,2). In the presence of a low concentration of glucose however, fructose, but not $\mathrm{N}$-acetylglucosamine, potentiated insulin release (Tables 1,2). Insulin release was also increased by leucine and its metabolite $\alpha$-ketoisocaproate, 3-hydroxybutyrate, and caffeine in the absence of glucose (Tables 1,2). Glucose-stimulated insulin release was potentiated by $5 \mathrm{mmol} / \mathrm{l}$ caffeine and was inhibited by $25 \mu \mathrm{mo} / / 1$ trifluoperazine (Table 2).

\section{Discussion}

The absolute rates of glucose-stimulated insulin release from the human islets in the present study are similar to those previously reported. In non-cultured islets isolated from the pancreas of a 4-year old girl undergoing surgical pancreatectomy for idiopathic hypoglycaemia, insulin release was $25 \mu \mathrm{U} /$ islet/h at 
$16.7 \mathrm{mmol} / 1$ glucose [6]; in human islets cultured for one week insulin release was increased from 12.5 to $22.5 \mu \mathrm{U} /$ islet $/ \mathrm{h}$ on raising the glucose concentration from 3.3 to $16.7 \mathrm{mmol} / 1$ glucose [7].

In the present experiments the secretory response to glucose was preserved following three successive periods of culture and incubation: this technique greatly expands the amount of information to be gained from a single batch of islets and in view of the scarcity of suitable tissue represents a valuable procedure.

Although the present results are derived from a single preparation of human islets, we have felt it useful to report them since there is to our knowledge no other report on the specificity of insulin secretory responses in human islets. In general the main features provide encouraging support for the view that data and hypotheses derived from rodent islets [8] may be applicable to man. Thus, in agreement with studies on rat and mouse islets [9-11] the order of potency of hexoses was glucose $>$ mannose $>>$ fructose. Fructose, indeed was only stimulatory in the presence of low glucose: this potentiatory behaviour of fructose is well-documented in rat islets $[9,11]$. The secretory response to dihydroxyacetone, which in rodent islets has provided support for the substrate-site hypothesis' [12], was evident in the human islets. Similarly, the ability of leucine and its metabolite $\alpha$-ketoisocaproate to initiate insulin release from rodent islets $[13,14]$ was also demonstrated with the human islets.

Stimulation of insulin release by ketone bodies has previously been observed in dog in vivo [15] and in vitro in rat pancreas pieces [16]. This effect has been suggested to play a role in the glucose-fatty acid-ketone body cycle [17]. However other workers have failed to find stimulation of insulin release by ketone bodies in vivo in man [18] or in vitro in rabbit pancreas pieces [19] or isolated rat islets [20]. The present finding of enhanced insulin release from human islets by ketone bodies shows that direct stimulation of the pancreatic B-cell by 3-hydroxybutyrate may indeed participate in the glucose-fatty acid-ketone body cycle.

Potentiation of glucose-stimulated insulin release from human islets by caffeine found here confirms a previous observation on human islets [6] and is also in agreement with observations on rodent islets [21]. It is noteworthy that caffeine alone elicited a modest stimulation of insulin release. Recent studies on the mechanism of stimulus-secretion coupling in rat islets of Langerhans have implicated calmodulin as a possible component of $\mathrm{Ca}^{2+}$-dependent exocytosis [22]: evidence for this hypothesis includes the inhibitory action of trifluoperazine, a specific inhibitor of cal- modulin [23], on glucose-stimulated insulin release. Similar results have also been obtained in adrenal medulla [24] and sea urchin eggs [25]. The inhibitory action of trifluoperazine on glucose-stimulated insulin release from human islets, found here, permits the extension of these speculations to insulin secretion mechanisms in man.

The sole discrepancy observed in the present study is the failure of $\mathrm{N}$-acetylglucosamine to initiate or potentiate insulin release from the human islets, in marked contrast to its effects on rat islets [26]. This finding is however consistent with our inability to elicit insulin release by infusion of $\mathrm{N}$-acetylglucosamine into healthy human subjects (unpublished observations). In rat islets, the ability of Nacetylglucosamine to initiate insulin release is attributed to the ability of the islets to metabolize Nacetylglucosamine, via a specific $\mathrm{N}$-acetylglucosamine kinase $[8,26,27]$. The present finding could be rationalized within the framework of the substratesite hypothesis if human islets were found to lack $\mathrm{N}$-acetylglucosamine kinase.

Acknowledgements. We thank Prof. P. Morris, Mr. Michael French and colleagues for access to surgical material; and the Medical Research Council, the British Diabetic Association, the British Insulin Manufacturers and Oxford R. H. A. Research Scheme for grants towards the costs of these investigations.

\section{References}

1. Hellerström C (1968) Method for microdissection of intact pancreatic islets of mammals. Acta Endocrinol (Kbh) 45:122-132

2. Moskalewski S (1965) Isolation and culture of the islets of Langerhans of the guinea pig. Gen Comp Endocrinol 5: $342-353$

3. Krebs HA, Henseleit K (1932) Untersuchungen über die Harnstoffbildung im Tierkörper. Hoppe Seylers Z Physiol Chem 210: 33-66

4. Coll-Garcia E, Gill JR (1969) Insulin release by isolated pancreatic islets of the mouse incubated in vitro. Diabetologia 5: $61-66$

5. Ashcroft SJH, Crossley JR (1975) The effect of glucose, Nacetylglucosamine, glyceraldehyde and other sugars on insulin release in vivo. Diabetologia 11: 279-284

6. Ashcroft SJH, Bassett JM, Randle PJ (1971) Isolation of human pancreatic islets capable of releasing insulin and metabolising glucose in vitro. Lancet I: $888-889$

7. Andersson A, Borg H, Groth C-G, Gunnarsson R, Hellerstrom C, Lundgren G, Westman J, Ostman J (1976) Survival of isolated human islets of Langerhans maintained in tissue culture. J Clin Invest 57: 1295-1301

8. Ashcroft SJH (1980) Glucoreceptor mechanisms and the control of insulin release and biosynthesis. Diabetologia 18: 5-15

9. Ashcroft SJH, Bassett JM, Randle PJ (1972) Insulin secretion mechanisms. Diabetes 21 [Suppl 2]: 538-545

10. Ashcroft SJH, Lowry M (1979) $\beta$-cell recognition of stereoisomers of D-glucose. Diabetologia 17: 165-168

11. Zawalich WS, Rognstad R, Pagliara AS, Matschinsky FM 
(1977) A comparison of the utilisation rates and hormonereleasing actions of glucose, mannose and fructose in isolated pancreatic islets. J Biol Chem 252: 8519-8523

12. Hellman B, Idahl L- $\AA$, Lernmark $\AA$, Sehlin J, Täljedal I-B (1974) The pancreatic $\beta$-cell recognition of insulin secretagogues. Comparison of glucose with glyceraldehyde isomers and dihydroxyacetone. Arch Biochem Biophys 162: 448-457

13. Ashcroft SJH, Weerasinghe LCC, Randle PJ (1973) Interrelationships of islet metabolism, adenosine triphosphate content and insulin release. Biochem $\mathbf{J}$ 132: 223-231

14. Panten U, Kriegstein E, Poser W, Schonborn J, Hasselblatt A (1972) Effects of L-leucine and aketoisocaproic acid upon insulin secretion and metabolism of isolated pancreatic islets. FEBS Lett 20: 225-228

15. Balasse E, Couturier E, Franckson JRM (1967) Influence of sodium beta-hydroxybutyrate on glucose and free fatty acid metabolism in normal dogs. Diabetologia 3: 488-493

16. Malaisse WJ, Malaisse-Lagae F (1968) Stimulation of insulin secretion by non-carbohydrate metabolites. J Lab Clin Med 72: $438-448$

17. Newsholme EA, Start C (1973) In: Regulation in metabolism Wiley \& Sons, London, p 231

18. Balasse E, Ooms HA (1968) Changes in the concentration of glucose, free fatty acids, insulin and ketone bodies in the blood during sodium beta-hydroxybutyrate infusions in man. Diabetologia 4: 133-135

19. Coore HG, Randle PJ (1964) Regulation of insulin secretion studied with pieces of rabbit pancreas incubated in vitro. Biochem J 93: 66-78

20. Montague W, Taylor KW (1968) Regulation of insulin secretion by short-chain fatty acids. Nature 217: 853
21. Sharp GWG (1979) The adenylate cyclase-cyclic AMP system in islets of Langerhans and its role in the control of insulin release. Diabetologia 16: 287-296

22. Sugden MC, Christie MR, Ashcroft SJH (1979) Presence and possible role of calcium-dependent regulator (calmodulin) in rat islets of Langerhans. FEBS Lett 105: 95-100

23. Levin RM, Weiss B (1977) Binding of trifluoperazine to the calcium-dependent activator of cyclic nucleotide phosphodiesterase. Mol Pharmacol 13: 690-697

24. Baker PF, Knight DE (1979) The 'leaky' adrenal medullary cell. TINS 2: 288-291

25. Baker PF, Whittaker MJ (1979) Trifluoperazine inhibits exocytosis in sea-urchin eggs. J Physiol (Lond) 298: $55 \mathrm{p}$

26. Williams IH, Ashcroft SJH (1978) N-acetylglucosamine and the substrate-site hypothesis for the control of insulin biosynthesis and secretion. FEBS Lett 87: 115-120

27. Ashcroft SJH (1978) The use of glucose analogues in the elucidation of the mechanisms of insulin release and biosynthesis. FEBS 11th meeting 42 (Symp A1): 227-236

Received: April 15, 1980, and in revised form: May 12, 1980

Dr. S. J. H. Ashcroft

Nuffield Department of Clinical Biochemistry

John Radcliffe Hospital

Headington

Oxford

England 